\title{
The Warp and the Weft: A Teaching Stories Tools Ensemble
}

\author{
Bia Machado \\ Philosophy Department, University of São Paulo
}

\begin{abstract}
Multidisciplinarity has led researchers to study not only connections among disciplines but, in a broader perspective, among other cultures and other periods in History. Ibn 'Arabi (13 ${ }^{\text {th }}$ century), one of the greatest mystics of Islam, with a large influence over thinkers in the West - such as Duns Scott and Dante - is a major example of how "ancient" knowledge can enlighten very contemporary matters and work together with current life and thought.

The present work, the result of 20 years of academic and field research, is the introduction of a teaching ensemble of tools from a pedagogical model built through the combination of some medieval complex concepts of singularity and imagination with post-modern conceptions of psychology and education. It consists in a process of working with old teaching stories under analogical structures and a contemporary exploration of Ibn 'Arabi's concept of creative imagination.
\end{abstract}

\section{Introduction}

The Philosophical Tradition of the $20^{\text {th }}$ Century has extensively criticized the individual and social fragmentation in all areas of human culture as a consequence of Modernity. The desenchantment of the world - this all-embracing expression coined by Max Weber in his classic "The Protestant Ethic and the Spirit of Capitalism" - has produced undeniable development of society, from the creation of human rights to nature's domination, but it has also driven man to conform himself into the long term destructive pattern of "discipline and punishment", according to one of Foucault's major works [1].

Nowadays, multidisciplinarity is one of the attempts to cumulate this structural problem and offer adults and children experiences of totality, in order to regain skills of dealing with the whole, or, remembering the idea of german philosopher Walter Benjamin - that modern men are surrounded by the city while in former times they were situated in the
Cosmos - in order to be able to think and imagine beyond the artificial methods of "modern reason", as an organic experience with concrete demands of reality.

Multidisciplinarity, however, understood as the mind model of interconnection among disciplines, would not fulfill all its potentialities without including both transcultural and transhistorical approaches: if our world is a desenchanted one, what have we lost from ancient times - the Enchanted World, as we would call it - that could be valuable today, in our very present lives?

In the last 20 years, at the University of São Paulo (FFLCH - USP), we have developed researches guided by this perspective [2], [3]. As a result, we created the "Caleidoscope ModelModelo Kaleidoscópio" (Kaleidoscope Model), a pedagogical construct oriented towards teachers and learners of all ages.

In its theoretical fundamentals, the Kaleidoscope Model (KM) comprehends a broad articulation between Contemporary Philosophy (mainly: Merleau-Ponty [4], Freud [5], Lacan [6], Foucault [7] and Derrida [8]) and the "Enchanted Philosophy" of Muhyiddin Ibn Arabi [9], [10], one of the greatest masters of Sufism - a Islamic mystical path - who lived in the $13^{\text {th }}$ Century, in Mourish Spain.

In one of its application tools, the KM brings forward a pedagogical process based on sufi teaching stories and Ibn 'Arabi's concept of creative imagination - the Teaching Stories Tools Ensemble (TeSTE).

\section{Inside the Kaleidoscope Model: the TeSTE fundamentals}

One of the "lost concepts" that researchers are nowadays able to retrieve from the Middle Ages in general and from Sufism and Ibn Arabi specifically is the one of self-knowledge. Differently from the modern idea of knowing one's personality, selfknowledge is a complex doctrine concerning the most profound constructions of an "enchanted" psychology. 
An illustrative view on this matter is given by the beautiful Sufi metaphor of the Persian carpet: to make a carpet, we must firstly fix the warp firmly on the loom and only then we can weave the weft over it. In the end, the weft is the visible design and the warp is the invisible web that sustains it. The more the warp is firm and the more we "obey" it, the freer we are to draw the weft we want to. The warp is one and the wefts are multiple, they vary according to anything we may imagine, they don't have to follow any pre-existing pattern, since their real basis is the warp. Their possibilities are endless.

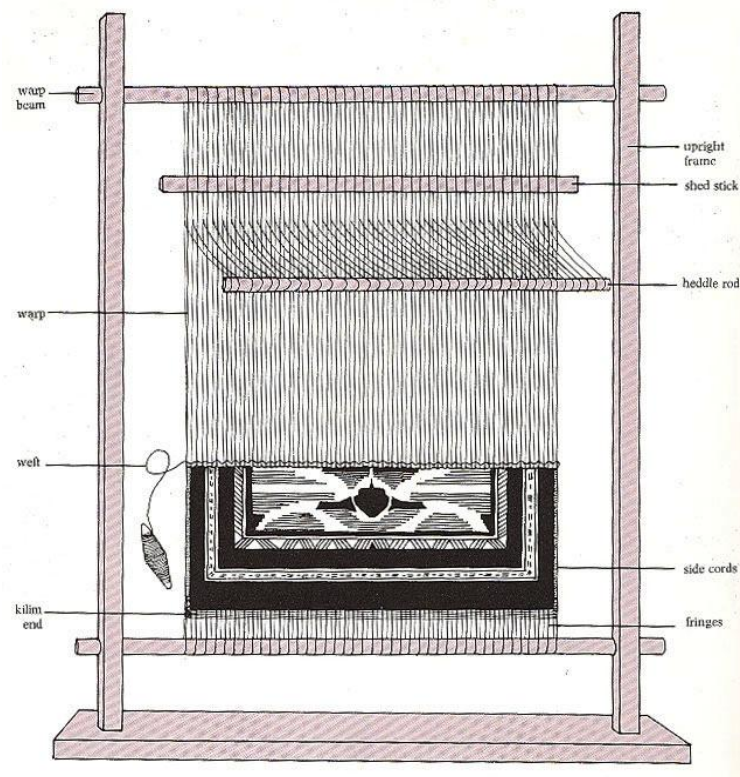

Figure 1. Warp \& weft

Comparatively, the modern idea of selfknowledge understood as knowing one's personality is similar to an attempt to know the weft, confounding it with the individual himself and, thus, seeing it as a fixed or a predictable or a definite reality. The "enchanted self-knowledge", on the contrary, implies the contact with the invisible warp that allows the manifestation of all kinds of being (wefts), the unpredictable, ever-changing and yet singular and unique inner reality. Which means this knowledge is also an ever-renewable knowledge, or, in other words, a never-ending creation of itself.

Basically, we are dealing here with a most complex idea of singularity, which will find substantial applications through a pedagogical perspective.

The teaching stories assembled by the Sufis throughout their Confraries' history are all Persian carpets: to try to analyse their wefts is to be deceived by their own ruses, but if you are able to establish a connection with the warp, you will "taste" the many possibilities of the story.

We are also dealing here with the idea of totality, understood not only as an intellectual or philosophical idea but mainly as an organic approach to reality. It is rather a mind model than a concept. The experience with a teaching story refers to totality, not by means of the weft (the visible plot). Although a story has always a beginning and an end, what is actually total is the warp, the structure behind the story that encompasses all variety of possible meanings and levels of significance [11].

Going along with the totality and the singularity, the Kaleidoscope Model envisages a third element, baptised, in a resonance with Hannah Arendt's work [12], as "symbolic public space".

Briefly, in our context, totality leads to autonomy; the singularity refers to both Derrida's understanding on the problem of relationship with the Other - after the deconstruction of certain psychoanalytical concepts - and Ibn 'Arabi's works on self-knowledge and self-creation; and the symbolic public space is the situation set to favour exchanges on warps-and-wefts experiences.

The main procedures of the Kaleidoscope Model happen within this setting, which is kind of an Agora, the Greek public place where citizens used to discuss their lives.

Finally, a last word on the central warp of all techniques used by the KM: the analogy.

The Enchanted World has seen analogy as the very structure of reality [13]. "What is below is like that which is above, and what is above is like that which is below..." says the famous alchemic aphorism. Modern Education has banished the analogy to the literature field, preventing it from "veiling" the logical, thus scientific thinking.

In our context, analogy will be a perspective. If we ask a child to make a drawing or a painting after hearing a story, it is most likely that he or she will try to illustrate the story, to describe it. But, if they have developed analogical skills, they will translate the story into the language of drawing or painting. Thus, they will be able to dance the story, or to make a cake that is the story, not one that represents it. Experiencing that any reality can be translated into any other, they will then learn that invisible reality may also be translated into a visible one ("What is below is like that which is above, and what is above is like that which is below..."), so they will find out that, under the proper circumstances, what they do (visible) can be a mirror of what they are (invisible).

The translator is able to translate a text from one language to another because he knows the structure of both languages and the operation of translating is analogical: chair in English corresponds to chaise in 
French (something "above" corresponds to something "below"). Translating a story into a painting, for instance, requires that the child connects herself with both the structure of the story and the language of painting, which means an experience of totality. When he or she learns to translate the story into themselves, this is an experience of "self totality", an experience of contact with his or her "own warp".

The idea of translation is fundamental. Any language is a warp in the sense that it is a structure by means of which we say anything we want, any weft. Apparently, we learn a language little by little while we experience its possibilities, but, in reality, we only know it when we learn to lock on the structure, when we have it inside, so to speak, as a totality. So it is very different to learn something than to learn a language: again, the latter requires a mental model of totality. That means that any child who speaks a language has this mental model as a concrete experience. It is not something thought or felt or perceived, it is behind any thought or feeling or perception. But it is also something very simple because any child has and uses it.

To understand a story not as a thing but as a language, means that anyone who reads or listens to it, beyond thinking or feeling or perceiveing, can lock on it. Let me give you an example.

Let's imagine the following situation: a child is crying. In our desenchanted world, what do we adults often do in such a circumstance? We ask him or her to stop crying and to explain what is happening. In order to correspond to our expectation, he or she will answer that they are, let's say, afraid (it is most likely that we are here dealing with anguish, not fear, but do their parents know the difference?). Of course, we will automatically ask: "afraid of what?". Again, he or she will try to content us and answer: "I'm afraid to be kidnapped by a terrorist". At that moment we are ready to repeat the old litany that there is no reason for fear because we will protect them, take care, etc, etc. Next week, a similar situation happens and we do everything the same way.

Let's leave the scene and dream as if we were now somewhere in the Enchanted World. A child is crying. We don't ask her to stop. We wait her to finish her working out of the situation. Then, we address her this very simple analogical question: "this, that you are tasting now inside yourself, if it were an animal doing something, which one would it be?".

So the relieved child, after having freed all its tears to the expansion of the atmosphere, will search inside and start: "it is a baby elephant who was trying to brush its teeth but he couldn't decide himself between the blue and the yellow shirt he had to put on in order to go to his brother's prom and so on...". And we, of course, will be frankly interested and curious about the story, allowing him or her to develop it freely. Next week, a similar situation happens and we do everything the same way.

But the story, evidently, is a different one: it is now this joyful zebra using red striped socks speaking at its striped iphone with his mom...

Some differences between the two experiences: in the first one, the expression "I'm afraid" is supposed to describe the inner reality of the child. But we all know - the child include - that fear is a feeling, not a reality, many things are missing here. Some of us also know that anguish is the inner experience of something that hasn't yet took a form, an expression, a ground to land, and because it hasn't, it is experienced as fear or as something frightening unknown. Next week, the child is "afraid" again, after some other experiences like that, he or she will be totally convinced: "I'm fearful, timid...". The word-label "fear" will lead to identity labelling, to fix a single and rigid weft.

In the second experience, the story translates the inner reality because it is analogical. All the elements are there, the flow, the shapes, the atmosphere, the spirit. The anguish met the ground of a narrative, a language to "speak", a form for the Real. Next week, the experience is totally different, there is nothing to be ascribed to the being, there is no pattern nor repetition. Nothing identical, no identity. The enchanted self-knowledge claims that knowing yourself is not knowing that you are this or that, that you have such and such qualities or weaknesses. Technically we should say that first of all "you are nothing", as Saint Teresa and so many others would say, and secondly, which is the same, you are a magician hat.

I heard a sufi master saying once in Turkey: "Western people are very funny, they say: 'I'm sorry but I'm just like that', when they are not sorry and they are not like that".

This very simple example of a child's narrative as a tool of real communication and as a bridge from the invisible inner world to the tangible form of a story is in fact a door towards an entire perspective.

If a child can learn - by experience, not because someone told her or him - that to communicate inner reality does not lead to the labeling from others, that the listening from the other is a way to enhance inner reality, that the result of that sort of relationship is discovering, not fixing, that she or he are not compelled to fuel judgement nor to be anything to others because in this relationship everything is everchanging, then we begin to imagine what, for instance, Aborigines from Australia mean by 
'songlines' or what the Sufis understand by safar to travel within Existence.

The arabic word for translator-interpreter is tarjumân. Interesting to observe that nowadays in our society these two meanings are often opposed.

"The universe is a book, a "great Qur'ân" (...). Conversely, the Book is a universe. To speak of the one is to speak of the other. There is an intermediary between these two universes - or these two Books. It is man - the insân kâmil (perfect man), of course who shares the nature of both. He is both "brother of the Qur'ân" and 'alâm saghîr, the "little world", or microcosm. It is to him that the divine discourse is addressed in this double form, and it is his duty to decipher it, to be simultaneously tarjumân al-qur'ân and tarjumân al-'alâm, interpreter of the Qur'ân and interpreter of the created world; he is the one that gives them meaning." [14]

What Derrida called Écriture, the sufis call the Holy Book or the universe. To give meaning to anything is to be real. Ecriture, the world and men can be mutually translated, in which case selfknowledge can be said self-translation and translation of the world. Inner and outer world are not separated, nor knowledge and action and love. That's why art and science are languages for the spiritual ever-parlance of any child and can be meaningful if they are seen as languages, not as savoir de survol, to quote Merleau-Ponty's fortunate expression.

Of course, when the sufis envisage imagination they are talking about something unattainable for non-initiated ones. But, in our context, we understand that Education can be inspired by their wisdom, as it has been in previous times.

The pedagogical consequences of such a perspective are evidently vast. To point out just one of them, let's say that the teaching stories are analogical structures of human functioning [15] and any child or any adult can be a tarjumân of himself by means of locking on analogically with it.

The Teaching Stories Tools Ensemble (TeSTE) consists in exploring some of the consequences of this special kind of experiences.

\section{The TeSTE}

The TeSTE is conceived for adults and children, teachers and students. As a starting point, a group of schoolteachers will be familiarized with the process so that they will be prepared to participate in a forthcoming process with their students. The whole process consists of 6 steps, as following (see Table 1):

Step 1: Preparation - definition of some guidelines, change parameters and beacons of evaluation by identifying challenges that teachers have in their daily activities at school.

Step 2: Working with analogies - at this step the idea is to learn how make analogies and how to practise it.

Step 3: Learning how to learn from teaching stories - the main idea here is to find analogies between the stories and personal inner experiences.

Step 4: Working with complex analogy - the group must now be ready to make analogies between stories and other languages (dance, music, etc.), to translate stories into artistic languages.

Step 5: Working with a specific story: "Prince Adil and the lions" - to experience changing effects of analogical structures by means of analogically following the "guidelines" present in the structure of this story.

Step 6: Results analysis - repeating step 1 procedures to compare initial and final speeches by means of pre-established change parameters.

We were glad to present the TeSTE research project at the World Congress of Education, held in London last year. Having had interesting discussions among colleagues at the WCE, we submitted it to a Brazilian institution of children education and are now preparing to start the research's first steps. The research's objective is to explore the TeSTE in a teaching context.

\section{Conclusion}

The idea that the TeSTE can produce "change" should not be understood as a behavioral kind of transformation. The core here is that self-knowledge, as said before, from an enchanted perspective, is always change, movement, ouvertures. It means that we can, of course, have change of behavior or of state or any other kind of perceptible changes, but we do not seek for that specific sort of result. Nevertheless, we are dealing with change parameters during the whole process, like, for instance, social and personal skills. In our experience, the creative potential of analogy structures often leads people to happy achievements, which tend to create an atmosphere of contentment, trust and relaxation within the "symbolic public space", favouring the development of such personal and social skills.

What really matters in this perspective is that we are developing tools of self-observation: achieving familiarization with teaching stories leads to seizing structures of human functioning, thus, means of observation under concrete situations and not in an abstract way. Being different kinds of mirrors, the stories are kaleidoscopes in which observing, knowing and changing are levels of the same paradigm. 
Table 1. Procedures

\begin{tabular}{|c|c|c|c|c|}
\hline steps & what & what for & how & duration \\
\hline $\begin{array}{l}\text { step } 1 \\
\text { Preparation }\end{array}$ & $\begin{array}{l}\text { establishing } \\
\text { beacons of evaluation } \\
\text { (using parameters from } \\
\text { KM's methodology). }\end{array}$ & $\begin{array}{l}\text { to construct a } \\
\text { baseline for } \\
\text { subsequent } \\
\text { analysis of results }\end{array}$ & $\begin{array}{l}\text { identifying } \\
\text { challenges that } \\
\text { teachers have in } \\
\text { their daily } \\
\text { activities at school }\end{array}$ & - 6 hours \\
\hline $\begin{array}{l}\text { step } 2 \\
\text { working with } \\
\text { analogies }\end{array}$ & $\begin{array}{l}\text { learning how to perceive } \\
\text { and work with structures } \\
\text { (in order to build } \\
\text { analogies) }\end{array}$ & $\begin{array}{l}\text { to get participants } \\
\text { skilled in building } \\
\text { analogies }\end{array}$ & $\begin{array}{l}\text { exercises with } \\
\text { poems, texts, } \\
\text { objects, etc. }\end{array}$ & $\begin{array}{l}\text { - } 1 \text { month } \\
\text { - } 3 \text { hs / week } \\
\text { - total: } 12 \text { hours }\end{array}$ \\
\hline $\begin{array}{l}\text { step } 3 \\
\text { learning how to } \\
\text { learn from } \\
\text { teaching stories }\end{array}$ & $\begin{array}{l}\text { to get participants } \\
\text { familiar with teaching } \\
\text { stories structures }\end{array}$ & $\begin{array}{l}\text { to apprehend the } \\
\text { story as a whole } \\
\text { and to relate it } \\
\text { with oneself }\end{array}$ & $\begin{array}{l}\text { finding analogies } \\
\text { with personal } \\
\text { inner experiences }\end{array}$ & $\begin{array}{l}\text { - } 1 \text { weekend } \\
\text { - total: } 12 \text { hours }\end{array}$ \\
\hline $\begin{array}{l}\text { step } 4 \\
\text { working with } \\
\text { complex analogy }\end{array}$ & $\begin{array}{l}\text { making analogies } \\
\text { between stories and } \\
\text { other languages (dance, } \\
\text { music, etc.) }\end{array}$ & $\begin{array}{l}\text { to get participants } \\
\text { able to work } \\
\text { within languages }\end{array}$ & $\begin{array}{l}\text { "converting" } \\
\text { stories into artistic } \\
\text { languages (dance, } \\
\text { music, etc.) }\end{array}$ & $\begin{array}{l}\text { - } 1 \text { month } \\
\text { - } 3 \mathrm{hs} / \text { week } \\
\text { - total: } 12 \text { hours }\end{array}$ \\
\hline $\begin{array}{l}\text { step } 5 \\
\text { working with a } \\
\text { specific story: } \\
\text { "Prince Adil } \\
\text { and the lions" }\end{array}$ & $\begin{array}{l}\text { to use the structure of } \\
\text { the story as a tool of } \\
\text { inner organization }\end{array}$ & $\begin{array}{l}\text { to experience } \\
\text { changing effects } \\
\text { of analogical } \\
\text { structures }\end{array}$ & $\begin{array}{l}\text { following the } \\
\text { "guidelines" } \\
\text { present in the } \\
\text { structure of this } \\
\text { story }\end{array}$ & $\begin{array}{l}\text { - } 1 \text { weekend } \\
\text { - total: } 12 \text { hours }\end{array}$ \\
\hline $\begin{array}{l}\text { step } 6 \\
\text { results analysis }\end{array}$ & $\begin{array}{l}\text { repeating step } 1 \\
\text { procedures }\end{array}$ & $\begin{array}{l}\text { to compare initial } \\
\text { and final speeches }\end{array}$ & $\begin{array}{l}\text { by means of } \\
\text { change parameters }\end{array}$ & $\begin{array}{l}\text { - } 1 \text { weekend } \\
\text { - total: } 12 \text { hours }\end{array}$ \\
\hline
\end{tabular}

\section{Acknowledgements}

I would like to thank FAPESP for their support and research funding. Also my colleague Olga Modesto, co-developer of KM, and Tami Buzaite, for english revision of this article.

\section{References}

[1] M. Foucault, Surveiller et punir, Paris, Gallimard, 1975.

[2] B. Machado, Sentidos do Kaleidoscópio, Ed. Humanitas, São Paulo, 2004.

[3] B. Machado, A Trama e a Urdidura, Tese de Doutorado, Faculdade de Filosofia, Letras e Ciências Humanas da Universidade de São Paulo, 2010.

[4] M. Merleau-Ponty, Le Visible et l'invisible, publié par Cl. Lefort, Paris, Gallimard, 1964.

[5] S. Freud, Obras Completas, Imago, São Paulo, 2006.

[6] J. Lacan, Écrits, Ed. Du Seuil, Paris, 1966.
[7] M. Foucault, Histoire de la sexualité, Gallimard, Paris, 1976.

[8] Derrida, L'Écriture et la différence, Ed. Du Seuil, Paris, 1967.

[9] M. Ibn Arabi, Fusus al-Hikam, (Le Livre des Chatons des Sagesses), Ed. Al-Bouraq, Beyrouth, 1997.

[10] M. Chodkiewicz, Le Sceau des Saints, Gallimard, Paris, 1986.

[11] I. Shah, A Perfumed Scorpion, Octagon Press, London, 2000.

[12] H. Arendt, The Human Condition, Universtiy of Chicago Press, $2^{\text {nd }}$ edition, 1998.

[13] H. Corbin, L'Imagination Créatrice dans le Soufisme d'Ibn Arabi, Flammarion, Paris, 1958.

[14] M. Chodkiewicz, Introduction, in Ibn al-'Arabi, The Meccan revelations, Pir Press, New York, 2004, p. 27.

[15] I. Shah, Learning how to learn, Penguin Books, London, 1996. 